\title{
Structure and Message in Trobriand cricket
}

Jerry W. Leach

\section{OpenEdition}

Journals

Édition électronique

URL : https://journals.openedition.org/tc/195

DOI : $10.4000 /$ tc. 195

ISSN : 1952-420X

\section{Éditeur}

Éditions de l'EHESS

\section{Édition imprimée}

Date de publication : 1 juin 2002

ISSN : 0248-6016

\section{Référence électronique}

Jerry W. Leach, « Structure and Message in Trobriand cricket », Techniques \& Culture [En ligne], 39 | 2002, mis en ligne le 13 juin 2006, consulté le 29 septembre 2022. URL : http:// journals.openedition.org/tc/195; DOI : https://doi.org/10.4000/tc.195

Ce document a été généré automatiquement le 29 septembre 2022

Tous droits réservés 


\title{
Structure and Message in Trobriand cricket $^{*}$
}

\author{
Jerry W. Leach
}

1 Trobriand cricket was made during a period in anthropology when attention was, and still is, focused on the message-bearing aspects of social behaviour. This dominant concern is expressed in the film and this paper is about how messages were built into the whole film through the interrelations of its basic parts, images and words.

2 The backbone of the film is the relationship between the images of which there are 316 (296 moving and 20 still). These were selected from about 2500 images available when editing began. In anthropological films, it is because one can do little to expand the available set of images after the field period, while the verbal level of the film can be continuously re-shaped to the end of editing, that the relations between pictures tend to form the basic framework of most works. And to obviate the obvious, the medium is film, not written pages.

3 The framework of images in Trobriand cricket, however, does not rest on a natural chronology of events. This means that the basic sub-divisions of the film are not related to each other because event $\mathrm{X}$ of the subject matter happens before event $\mathrm{Y}$. There is, however, natural sequencing of images within the sections of the film, especially the game block. The major linkages among the sections, though, are conceptual and came about, consciously and unconsciously, in the filmaking process. What is presented here are the synchronic results of decisions taken diachronically and in a piecemeal fashion. Those decisions unfold diachronically in the film but are intented to lead to a synchronic reconstruction of the meaning of the film in the mind of the viewer after seeing the whole. This paper presents what that intented reconstruction is while fully accepting that each viewer, because of his special interests, will understand the film in some variant way.

Major Messages

4 There are three basic ways of looking a how the images and verbal statements of Trobriand cricket are sub-divided and how these sub-divisions are related to each other. There are, in other words, three simultaneous structures to the whole and the major 
messages of the film occur through the imposed sequencing of the parts and the interrelations of their verbal and visual contents.

5 Message level 1. Here the film is built on an opposition between Block A, the opening one minute 32 second section ending with the title, and Block B, the remaining 52 minutes.

Block A is based on two presumptions : (1) that viewers know they are going to see something about cricket, and (2) that they have some preconceptions about how unfamiliar and unlike themselves the bahaviours of remote peoples are. Block A panders to that stereotype saying "Here is cricket-but with near-nudity, painted bodies, perpetual noise, dancing, bent-arm bowlers and slugging batsmen! Is this not proof of how other-than-yourself these distant people really are? » The intended effect of «chaotic and ridiculous behaviours " in Block A is enhanced by choppy shots, a slight shrillness in the sound track, and wobbly camera work plus the lack of any verbal statement explaining the images. If achieved, the effect should have viewers at the end of Block A saying «I can never see myself doing what I have just seen » or more simply « How absurd !»

7 A nuance of editing in Block A deserves mention here. The opening image is a ball on the ground, followed by a painted and feathered bowler who, with arm bent, throws a full toss. The closing image of Block A is a batsman poised in a roughly familiar fashion in front of a wicket, followed by his widly gyrating swing at the ball. The major message of Block A is here played again in a minor mode, punctuating the begining and end of the section. The superficially familiar becomes jarringly something very unfamiliar, reinforcing the distantiation between the viewer and the players.

Block B, the final 52 minutes, is a continous attempt to break down the distantiation of Block A and the stereotype which lies behind it. The near-nudity is seen in a context of tropical heat and is further explained as war dress now adapted for a similar type of ritualized competition but also having stimulus value with female spectators. Body painting becomes a conventionalized consciousness-changing device allowing players heightened courage in the game and extra-normal freedom in entering the eroticized relationship between players and crowd. Chants and dances are a part of that eroticized relationship as well as the new purpose for playing, i.e. displaying rather that winning, while at the same time being a syncretic re-emergence of customs (harvest dances, tugo-wars, and chants) formerly opposed and under threat of extinction. Bent-arm bowlers are found to be behaving in the natural manner of Trobriand spear throwers. Slugging batsmen fit the rhythm of the game and become understanble in light of having runners do the scoring, having batsmen face so many fielders, and having the hitting of sixes as the main road to individual distinction.

Every element of Block A should stand verbally and visually explained by the end of the film. It is a part of the process of breaking down distantiation that each Block A image be seen in close-up and from different perspectives in Block B, allowing the viewer to build up a perceptual grid of how to perform each action. In addition, Block B turns the personalityless object-people of A into subjects who have names, speak idiomatically, have a purpose for being in the film, and feel joy and pain where viewers presumably would too. The intended effect of Block B, the opposite of A, is for viewers to come away saying "I can do what they are doing and wish I had the chance " as well as feeling «I would like to know those people.» Otherness becomes cognitively and 
emotionally familiar, a representation of something already there in the mind of the viewer.

Message level 2. The second of the three simultaneaous levels of basic sructure in Trobriand cricket comes through another binary division. The two divisions are Block M, the first 20 minutes up to the date, and Block $\mathrm{N}$, the remaining 33 minutes. The relationship between the two parts is, however, not that opposition but of complementarity.

The principal reason for this division is that Block $\mathrm{N}$ could be, with a re-written commentary, a self-contained short film in itself. A condition of the sponsorship of the project by the Government of Papua New Guinea was that the results be presentable to the people of many societies of that country. The built-in short form of the film was a safeguard in case the long form did not have sufficient appeal.

This aspect of the structure is not message-bearing of course. At another level, however, the M-N division does have message intent. Block M's main task is to explain Trobriand cricket in advance of seeing it in full chronological form in Block N. Block M is relatively timeless, i.e. outside of real time, because it carries the greater part of the burden of explaining the abstract form of the game. The beginning of Block $\mathrm{N}$ ends this sense of timelessness with a precise date which also signals the shift from nonchronological to chronological structure in the images. Block $\mathrm{N}$ continues, however, to explain the abstract form of the game while mixing that level, in a relatively balanced way, with explanation of the actual events of the 1974 game.

There are 17 fundamental points about the game and film in the whole 53 minutes and 12 of these occur in Block M. They are :

- Only men play;

- Two sides equal but no fixed number per team;

- War dress;

- Bowlers throw in spear-hurdling style;

- Runners, not batsmen, score 1-6 runs per hit;

- Outs by being caught, bowled out, run out;

- Dances to enter and leave field symbolize the theme of a side;

- Dances and chants celebrate every dismissal;

- War magic adapted to cricket;

- Games happen because of political strivings of leaders;

- Exchanges in valuable foodstuffs follow game and reciprocate everyone for services to the event; and

- Game evolved from British original.

In Block $\mathrm{N}$ come the five remaining points fundamental to the game and film :

- Games take one day;

- Umpires like former war magicians, act for and control their own sides;

- Games occur in « seasons ", i.e. many visiting teams against one host, during harvest period;

- Formal-informal victory convention; and

- The film is a sponsored event.

Except for points 15 an 16, each of these fundamentals is repeated at least twice in the film in order to make them retainable after viewing. The 12 points of Block $\mathrm{M}$ are all restated in different ways in Block $\mathrm{N}$ and in some cases, namely dancing, magic and exchanging, their meaning is expanded considerably. Almost all the fundamental 
information has been presented by the beginning of the game in Block N. Point 17 « the film is a sponsored event " appears at the beginning of N, so as to clarify the status of what is being watched, and at the end of the exchanges, reiterating the message and climaxing it with a statement of the Trobriand purpose for the film, i.e. « to show their fellow contrymen their game » hoping, it might be added, that others would adopt it.

While almost all the fundamental information is being presented towo or more times, one crucial piece, the formal-informal victory convention, is held back until near the end of the game in Block N. This serves as kind of denouement satisfying the audience's expected curiosity about winning and losing. To make this point stand out the image background is very bland. The game winds down immediately after this conceptual climax.

One further point about the complementarity between Blocks $\mathrm{M}$ and N. Because Block M's basic function is to explain the abstract form of Trobriand cricket, it contains $53 \%$ of the verbal information (commentary and sub-titles) of the film even though it is only $38 \%$ or 20 minutes of the whole. Section $\mathrm{N}$ by design has more unverbalized space to allow viewers to get more «feel » of the game.

Message level 3. Trobriand Cricket's third level of simulateaous basic structure occurs through a division into five parts. These parts variously relate to each other through opposition, complementarity, and redundancy. Block V is the opening one minute 32 second section ending with the main sub-title An ingenious response to colonialism. Block $\mathrm{W}$ is the british-international cricket section. Block $\mathrm{X}$ is the history-abstract game section ending with the explanatory dance and chant material juste before the date. Block Y, starting with the date, includes the preparation-game-exchange sequence. Block $Z$ is the children's game including the credits.

It is impossible to cover here all the interrelations among the five blocks. The following three, however, are of considerable importance :

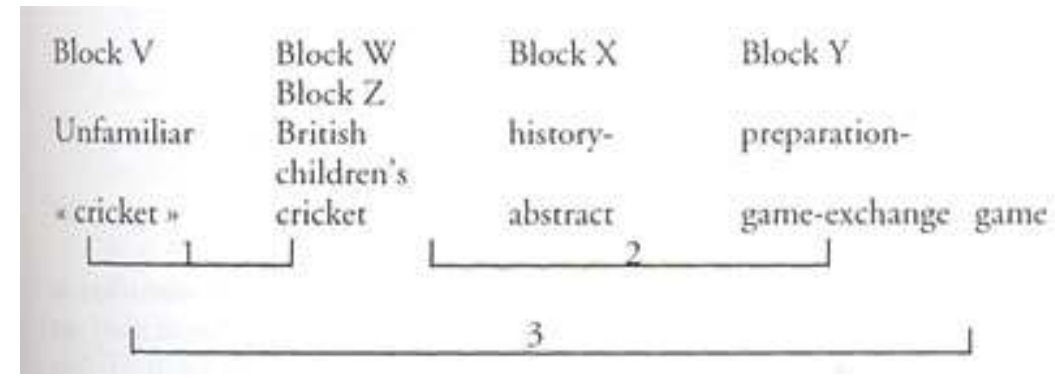

Concerning relation 1, the British cricket section is primarily there to give viewers in the non-cricketing parts of the world a brief image and account of the game. The section is, however, also intented to contrast with Block V, the opening version of unfamiliar "cricket». Block $\mathrm{W}$ is silent, but for commentary, as opposed to V's irrepressible noise. Block $\mathrm{W}$ contrasts as well by having white images, fully clothed players, less dynamic body movements, great distance between players and spectators, and relative emptiness on the playing field. From the starting unfamiliarity of Block V, the eye and mind return to the more familiar order of things briefly and the problem set is «How could the opening section's cricket » bear any relationship to "our " cricket? The similarities seem so superficial.

21 An imperfection of Block $\mathrm{W}$ should be noted her. The section ends with the line « The game is known fot its slow pace». In its context, this line seems to suggest that 
slowness is fundamental to the game, an assertion that many people would dispute. There is meaning, however, in this "mistake", or as it should be labelled, this editing compromise. First, coupled with the accented, i.e. outsider's commentary voice, this line and section should suggest that British cricket is susceptible to the same kind of analysis that Trobriand cricket is receiving. Secondly, the line has to say in words what is not « said » in the images, i.e. that cricket Trobriand-style does contrast in pace with British cricket. The shots available while making contrast in pace with British cricket. The shots available while making Block $\mathrm{W}$ did not allow the images alone to convey the "slow pace " message. Thridly and most importantly, Trobrianders say that many changes they introduced into the game they were taught came about because the original game was too slow for them. Unfortunately, none of the discussion material on the yamhouse or the field included this key point so the second-best choice of having the commentator make the point had to stand.

Relation 1, the contrast between Blocks V and W, should generate the question " How could their cricket bear any relationship to our cricket?». Relation 2 linking Blocks W$\mathrm{X}-\mathrm{Y}$, is a kind of answer to this pictorial question. Another diagram will help reveal how the « answer » is structured.

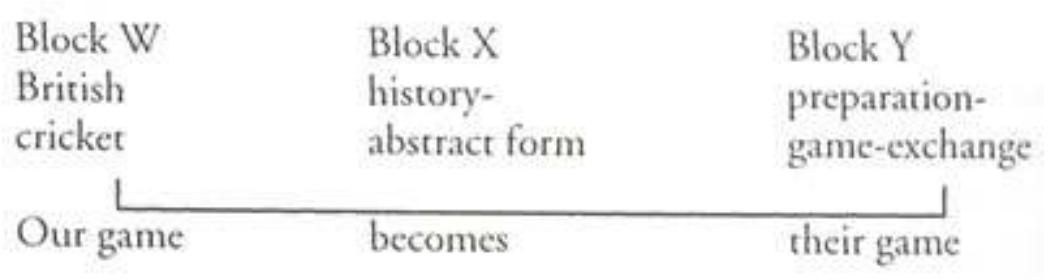

The " ourness » of " our game " places all viewers together as outsiders to Trobriand society due to the greater familiarity they will feel, even if they are non-cricketers, with the activities of Block $\mathrm{W}$ as opposed to Block $\mathrm{V}$. Taken together with the opening minutes of Block X, especially the colonial pictures, "our game" is taken to be a representation of what was actually imposed in a much larger process of cultural imposition. The colonial pictures also locate the process in historical time, setting up a time framework, i.e. 1903 today, so as to understand how long it took for the Trobriand transformations to take place.

Most of Block $\mathrm{X}$ is about the transformations. The main points of primary transformation are, in order of their appearance in the film :

Added chants and dances; mission clothes and because cricket was fought something like war; Changed from blocking with the bat to swinging to increase pace, display, and fun of the game; Changed from larger to smaller ball because of injuries;

Fielders changed from standing silent ans stationary to psyching out opposing batsmen to increase pace and spectacle and to give fielders something to do; Changed to Trobriand-style competition putting play under control of leaders because European-style competition caused too many quarrels and fights. Giving control to Trobriand leaders politicizes game by attaching it to their status-building processes thereby leading to the need to reciprocate people for their services to the event, hence exchanges begin; 

directions «Please talk about cricket». The sub-titles are fairly literally translated and represent about $80 \%$ of what is being said. The remaining $20 \%$, the least interesting

Techniques \& Culture, 39 | 2002 
remarks, do not appear because the speech in the sound track is faster thant the reading speed of the audience.

51 Finally, concerning relation 2 and the transformations of Block X, a caveat deserves sounding here. The yamhouse discussion of Block X presents a folk history and folk model of Trobriand cricket. The anthropological commentary following the discussions illustrates what has been said and then adds to it. At one point a divergence of interpretation between the folk history and the observer's historical model us gently indicated. The Trobrianders in the film suggest that all the transformations were made on Trobriand initiative while historical investigation gives prominence to the Polynesian missionarie, especially those from Samoa, as catalysts in certain changes.

Relation 3 (cf. supra) connects Block $\mathrm{V}$, the one minute 32 second opening section, with Block $\mathrm{Z}$, the one minute 19 second closing part which centres on the children's game. The relations between the blocks are those of complementarity and redundancy.

A form of open-ended thematic complementary in time is intended as one basis for the Block V - Block Z relationship. Block V shows scenes of an adult game in progress, the "now " of the game considered in relation to time. Block $\mathrm{Z}$ shows a practice game by young boys accompanied by the statements «Trobriand cricket has evolved from the parent game over the last 70 years » and "The game is still evolving ». The section then suggests the "predicted future » of the game, the underlying message being that the game of the film represents only one point in a series of continuous transformations through time and that this process will presumably not stop now. The boys are the future players who will make something yet again of the game.

There is in the film an example of the " continuous change-never freeze " nature of the game. The 1974 timed event was the first ever to have a mascot. The mascot was terrifically popular with all concerned due to his role-switching antics. He marched as an unserious "pilot» with his "plane» but later bacame the gawking «tourist». Unseen in the film he also mocked the cameraman by staring back at him through the wooden binoculars-cum-eyes-glasses-cum-camera. Apparently, the mascot, an ordinary villager who borrowed the bright clothes frome a medical orderly, dreamed up his function on his own. It was so popular that one suspects his innovation might catch on elsewhere.

The thematic redundancy in the Block V - Block Z relationship occurs through the linkage between the main sub-title an ingenious response to colonialism and the penultimate line in $\mathrm{Z}$ about the game's being a "creative adaptation of tradition to contemporary circumstances». Almost everything in the film should have a relationship to this grand theme and provide information for the viewer's questions « How is it ingenious? In what way is it a response to colonialism? How have Trobriand traditions been adapted to meet new circumstances?»

How is it ingenious? As mentioned, nearly everything in the film is part of the answer but the main points start with the Hula cricket section. Cricket was introduced all over Papua but largely remained the international version but for the Trobriands. The viewer should understand he is seeing a singular phenomenon which could have happened elsewhere but did not. Part of the meaning of «ingenious » lies in this contrast with other like societies. Another part of its meaning comes through correspondences with the development of British cricket seen in the history section. British cricket evolved through phases - as did its Trobriand counterpart. Forms of bowling changed to increase the pace and excitement fo the game -as with Trobriand 
cricket. Bats were once curved (for hitting into the ground) -while Trobriand bats become curved the other way (for hitting in the air). Scoring was by notching sticks analogous to using coconut fronds. The film suggests some parallels in the creativity at play of the British and Trobrianders.

More significant, however, in relation to the «ingenious " question are the crativity echoes found throughout the film between the statements of the grand theme "an ingenious response to colonialism" and a "creative adaptation of tradition to contemporary circumstances ». They are :

- « ...the game has undergone a remarkable cultural transformation ».

- « ...dances and chants have been especially created for the game ».

- «People have added so much... decorations and all...»

- « ...and then they made it our kind of competition».

- «So the mission game was already behind us ».

- «And sometimes the words have double meanings ».

- « People are always inventing new chants for cricket ».

- «People are really clever about these things ».

- «On the surface, the players make fun of themselves - but underneath they taunt their opponents- you'll see how blind we are! »

- (Seen en relation to the thrusting actions of the « tapioca » dancing spears) «Tapioca is a common phallic symbol and scraping it for cooking is an idiom for sexuality ».

- « ...PK relates the sure-handedness of the fielders to the stickiness of chewing gum » and is " ...a male term for a prostitute » here possibly meaning «I(we) can take on anybody ».

- (Seen in relation to the Aeroplane march-dance, especially the take-off) « A village on whose land a wartime airstrip was built call its team The "Aeroplane" ».

- (Seen in relation to the dance-swooping bird images) « As an out-dance the team symbolically becomes predatory sea birds ».

- "The mascot imitates a white tourist gawking at the people».

- «Which makes it our kind of cricket. Absolutely ! It's ours now. So white man's cricket... They've rubbished white man's cricket ! »

- The formal-informal victory convention (presumably relatively novel in relation to the world's games).

- «The leaders of the political movement who sponsored this film wanted it made to show their fellow countrymen their game » (presumably relatively novel in light of the purposes of other similar films).

These are the main parts of the answer to the question «How is it ingenious? »It should be noted, however, that the why question, i.e. "Why have Trobrianders been able to do all this while other groups have not?", is not answered in the film because that remains the major unanswered question in the minds of the filmmakers.

In what way is it a response to colonialism? Here the answer is based on a juxtaposition between inside and outside. Everything that comes from outside the islands is considrered part of colonialism. Without repeating the basic transformation lying behind today's cricket, which are responses to what was introduced, the following will note what the outside, i.e. colonial, condition are as presented in the film :

The form of cricket seen in the British cricket section was approximately what was introduced by missionaries.

«...British colonialism arrived in New Guinea » (seen in relation to flags and white masters). 
«Alien institutions were imposed on the people " (seen in relation to gunboats, naval officers, and exploring officials).

"Missionaries brought their own moral values... » (seen in relation to fully-clothed bodies, a Western-style husband-wife relationship, big houses, and domestic servants).

" ... Some of these institutions have taken hold in their familiar form - parliamentary democracy in the House of Assembly... ».

The cars and modern forms of dress that come with colonialism as seen in the images.

The « ...international equipment and techniques » plus the « overarm bowling » which come with introduced cricket.

The first players « ...just wore their mission clothes » (later seen in a still photograph).

At first « ...the bats were the white man's kind».

"When Mr. Gilmour taught people cricket they would block the ball with the bat ».

At first, « ...the mission converts used the white man's ball » because « ...white men had shown them that way ».

« ...Fijian missionarie... added ideas about how the game could be played ».

" The first players were early converts to the Methodist Church ».

At first « The game was played on the grounds of the mission head-quarters».

«Government control... was through resident officials - and the Papuan police force ».

«Traditional warfare was stopped» (by implication, just about the time cricket was introduced).

«... mission games were introduced for entertainment, as a substitute for warfare, and to encourage a new morality " (by implication, the new form of competition would be nicer and less violent).

The games were first played with 11 players plus a reserve, «the 12-players business ».

Europen-style competition meant face-to-face competition out from under the control of traditional leaders which somehow was not supposed to mean anything politically after the competition ended and the victor was clear.

« ... mission teams weren't allowed magic ».

The next intense phase of colonial imposition was World War II when land was taken, new machines first came, and new kinds of organization and activities among people were experienced.

Outsiders opposed « immoral dancing » (and by implication, « immoral chanting »).

The introduction of chewing gum brings a new quality to tactile experience.

By implication, modern imposed conditions coming from outside generate a political movement internally.

Outsiders come to make a film about cricket.

To repeat, it is what happens in relation to these conditions from the outside that is the «ingenious response to colonialism». Obviously, no particular feature or act of Trobriand creativity is being singled out. It is the quantity of such features as atotal package which deserves the accolade « ingenious response » in general terms.

How, then, have Trobriand traditions been adapted to meet new circumstances? » The answer exists in what has gone before but these are the basic points : 
Dancing has been given a new context.

Dances are crated out of some traditional dance movements and are representational the way some pre-cricket dances were.

Chants have been given a new context, having been formerly associated with tug-owars.

Chants have been linked up with the themes of the dances and the teams.

Bats are painted like war clubs were.

War dress has been maintained by carring it over as the uniform of cricket.

War magic has been carried over to cricket performing functions similar to those in warfare such as changing the course of the ball, formerly spear, in flight.

The custom of village corporateness in political affairs, mainly warfare, has led to the notion that men of a community should all be able to play cricket, therefore ending the 12-man rule.

Spear-hurdling, i.e. masculine, style of throwing has been maintained in bowling.

Trobriand-style competition has been integrated into the game, meaning traditional leaders have come to control the entire event and have to reciprocate people for their services to the event, hence a new context for the ceremonial exchanging of food. « Competition became ritualized -and also political» and is called « kayasa ».

Cricket has given leaders a new domain, similar to kula exchanging, gardening and formerly warfare, within which to compete for reputation.

The role of war magician has been maintained through merging it with that of umpire, changing both former positions considerably.

The tradition of festivities at the harvest period has been maintained by attaching «new » dances and chants to the game the missionaries introduced and have been proud of, making opposition hard to sustain.

Rain magic has been given a new context for performance and belief.

Counting by coconut frond has been maintained.

The reward exchanges of betelnut (seen during the post-game yam exchanges) have been given a new context.

Traditional leaders have come to head a political movement.

Finally, there is an intended message in the grand theme, « an ingenious response to colonialism » and " a creative adaptation of tradition to contemporary circumstances ", which is above and beyond cricket or Trobriand Islanders. It is related to the question «How does any of this have any relevance to me, the viewer?» The grand theme, if looked at beyond its space-and-time-bound anthropological context, says «Eve imposed changes can be handled creatively ", or put another way "Imposed conditions need not be always alienating because they can be given new meaning ». At this level of generality, the grand theme becomes, hopefully, a proposition about facting social change, especially when that change is imposed, seems out of control, or creates conceptual or emotianal difficulties in orienting to unasked-for circumstances. Thusly generalized, the grand theme would seem to be particularly relevant to facing the problem of neo-colonialism in Third World countries, i.e. whether or not things emanating from the outside world are to be rejected or accepted and, if so, how. In 
addition, it should be food for thought in the trying circumstances of any individual's life.

Minor messages

Minor messages are not necessarily related to the structure(s) of the whole of Trobriand cricket, but are messages, intended for special audiences, which may come from a single line or image, a particular section taken in isolation from the rest, or from the total configuration of the whole. The following are some of the mosst important ones.

First, for ethnographic filmmakers, is the idea that the people who are the subject matter can participate actively, not passively, in the filmmaking process. The notion lies behing the lines « ...the political movement which organized the activities for this film » and « ...(they) wanted it made to show their fellow countrymen their game », but most importantly it lies in the credit «With thanks for support, ideas, and organization to -The Kabisawali Movement ».

Second, for ethnographic filmmakers and anthropologists, Trobriand cricket suggests a solution to the frequent complaint among Thirs world peoples that outside academics treat, or at least present, the people being investigated as objects. Film is an excellent medium in which people can be subjects who speaks for themselves and have personalities. As a medium, film is probably more immediately appreciable than written pages in Third World settings. This is not to suggest that the conventional written core of academic anthropology, in style or content, should be replaced or altered. It does suggest, however, that film is a supplement to that core which fulfills certain valuable purposes better than the core itself. After all, the era is passed when anthropologists could assume that their research results woud not be seen or understood by the peoples investigated.

Third, for filmmakers, the commentator of ethnographic films should be the person who understands the subject matter best for reasons of nuance in tone and expression. The original plan of the film was to have an English speaking Trobriand commentator but when the sound-editing ended up in London this became impossible. The director, the actual commentator, became the second choice.

109 Fourth, for anthropologists, the magic material in Trobriand cricket draws attention, by implication, to one weakness in Malinowski's theory of magic. Malinowski wrote of magic as conservative in all its facets implying near immutability in its rites, spells, conditions of performance, purpose, and whatever. The film displays among Malinowski's own people how war magic has been taken over into cricket while retaining its verbal form and showing conservative parallelism in function.

110 Fifth, for students of anthropology, the films shows how intertwined are the observer's interpretation of events with those of the participants. At least in the fieldword-based tradition of anthropology, in which this films rest, the observer's analysis often begins with participant's interpretations, i.e. explanations of what something means or is all about, and even though the observer may go on th find unarticulated significance and new interrelations in his facts, his participants interpretations remain a kind of check on his theorizing.

111 Sixth, for those who may need to know, Trobriand cricket carries the message that darkskinned people are intelligent and creative. This message should come through their hopefully intelligible explanations of their activities, the quantity of changes they have made to cricket to make it theirs, the word-play and image-play of their chants and 
dances, their seizing on the film for a purpose of their own, and the credit which thanks them for their ideas.

112 And seventh, for Papua New Guineans, there is the dual message that some white people do admire village-level customs and that in Trobriand cricket there is a model of how to take parliaments, schools, money, canned food, cars, bureaucracy, English and make them one's own culturally.

Conclusion

This paper makes explicit, in a moderately formalized way, what some of the intended messages of Trobriand cricket are. The actual message to any given viewer or audience are, of course, another matter and open to further investigation. It is pleasing, however, to record in closing that the Trobriand sponsors of the film viewed it in January 1976, and gave it their approval as an accurate representation of their game and of themselves.

\section{Acknowledgements}

While this paper has a single author, the film itself has two, and grave injustice would be done to Gary Kildea were the reader not aware that many of the above ideas are his or were produced in an intense dialectic between anthropologist and filmmaker during 1974-1975 when the film was in its production stages. This acknowledgement is also a tribute to the amicable dedication of an excellent partner.

Trobriand cricket also recognized the informant contributions of John Mwakwabuya and kalitoni Pulitala plus the assistant directors' contributions ofGerald Beona and Bernard Mwayubu, all of the Trobriands.

Dr. Harry Powell deserves thanks for his permission to allow Trobriand cricket to include excepts from his film The Trobriand islanders and Mr. A. Nisbett of BBC-TV is gratefully acknowledged for help in acquiring authentic 1943 war footage from the Trobriands and for help in polishing the commentary.

118 The author wishes to thank Professor Sir Edmund Leach for teaching him what little he, the writer/filmmaker, knows of the relational theory of meaning, which lies in part behind the message structure of the film.

119 This paper is a modified version of the Notes to accompany the film Trobriand cricket distributed by University of California, Extension Media Center, Berkeley, CA 94720. It was originally written for the symposium «Problems of Anthropological filming" in Section $\mathrm{H}$ of the British Association for the Advancement of Science, University of Lancaster, Sept. 6, 1976.

\section{NOTES}

*. This paper was first published in Jack R. Rollwagen (ed.), pp. 237-251, Anthropological filmmaking : anthropological perspectives on the production of film and video for general public audiences. New York : Harwood Academic Publishers (1988). 


\section{RÉSUMÉS}

Ce texte est une version révisée des «Notes" afférentes à Trobriand cricket, film très connu parmi les anthropologues, qui fut réalisé à l'époque où leur attention se centrait (et c'est encore souvent le cas) sur le «message » décelable dans les comportements sociaux. Le thème principal de l'article se résume ainsi: comment les messages ont-ils été construits et insérés dans l'ensemble du documentaire, par le biais des relations entre ses bases constitutives, les images, le discours? En formalisant quelque peu, l'auteur rend manifestes certains de ces messages du film. Bien sûr, ceux que perçoivent de facto un spectateur ou un public donnés relèvent d'un autre registre et restent ouverts à des recherches ultérieures.

\section{Structure and Message in Trobriand cricket}

This paper is a modified version of the "Notes» to accompany the much talked-about film Trobriand cricket, that was made during a period in anthropology when attention was, and still is, focused on the message-bearing aspects of social behaviour. This dominant concern expressed in the article is about how messages were built into the whole film through the interrelations of its basic parts, images, and words. The author makes explicit, in a moderately formalized way, what some of the intended messages of Trobriand cricket are. The actual message to any given viewer or audience are, of course, another matter, and open to further investigation.

\section{El cricket de las Islas Trobriand : estructura y mensaje}

Este texto lo constituye una versión modificada de las « Notas » que respectan a Trobriand cricket, una película de mucha fama entre los antropólogos, que fue realizada cuando los trabajos de estos últimos enfocaban el «mensaje» traído por las conductas sociales (enfoque que sigue siendo vigente, a menudo). Una cuestión sintetiza el tema del artículo: ¿ De qué manera los mensajes han sido construídos e incorporados en el conjunto del filme, mediante las interrelaciones de sus partes básicas, de las imágenes y de las palabras? El autor elucida algunos mensajes del documental, formalizándolos en cierta medida. Por supuesto, los que perciben tal espectador o tal público son datos distintos que quedan abiertos para investigaciones ulteriores.

\section{AUTEUR}

\section{JERRY W. LEACH}

Falls Church, Virginia 